\title{
Clinical Evaluation of Direct Composite Resin Restorations in Fractured Anterior Teeth
}

\section{Evaluación Clínica de Restauraciones Directas con Resina Compuesta en Dientes Anteriores Fracturados}

\author{
Juan Carlos Ramírez Barrantes DDS, MS, PhD ${ }^{1}$; Edson Araujo Jr DDS, MS, PhD ${ }^{2}$;
} Luiz Narciso Baratieri DDS, MS, PhD ${ }^{2}$

1. Department of Restorative Sciences, Faculty of Dentistry, University of Costa Rica, Costa Rica

2. Department of Operative Dentistry, Federal University of Santa Catarina, Brasil.

Correspondence to: Dr. Juan Carlos Ramírez Barrantes - juancaramirezbarrantes@hotmail.com

Received: 10-VI-2015

Accepted: 28-VI-2015

\section{ABSTRACT}

The aim of this In Vivo study was to evaluate the influence of the cavosurface angle (with bevel, and no preparation), of direct composite resin restorations in previous fractured teeth after 4 years of clinical performance. The restorations were performed by a single operator, following a restorative standardized protocol. For the study were selected 24 upper central incisors with fracture or with class IV restorations with an indication of replacement. According to the restorative technique, the teeth were divided into 2 groups: group I $(n=12)$ Class IV Restorations with a bevel preparation technique; and group II ( $n$ = 12) Class IV Restorations performed with no preparation. The restorations were evaluated at 7 days and 4 years, by two examiners, previously calibrated using modified USPHS criteria. After 4 years, two restorations were excluded, representing 22 restorations (11 with bevel preparation, and 11 without). The Fisher test demonstrates no significant differences between groups $(p>0.05)$. This study presents clinical evidence that the cavosurface angle configuration does not influence the clinical performance of direct composite resin restorations in fractured teeth. Thus, we recommend no preparation of the cavosurface angle to preserve sound dental tissue based on a Minimally Invasive Dentistry approach.

\section{CLINICAL RELEVANCE}

The restorative protocol for restoration of fractured anterior teeth with composite resin aimed to practice a Minimally Invasive Dentistry approach involving the use of adhesive systems, previously proved into enamel and dentin histomorphology. There are reliable laboratory methods that determine an effective durable bond, therefore clinical research analyzing the long-term performance of the influence of the bevel configuration (with bevel and no preparation) of direct adhesive restorations with composite resin in anterior teeth fractured remains scarcity.

\section{KEYWORDS}

Minimally Invasive Dentistry, Composite Resin, Direct Adhesive Restoration, Bevel Configuration, USPHS Criteria.

RAMÍREZ, J., ARAUJO, E. \& NARCISO, L., 2014: Clinical Evaluation of Direct Composite Resin Restorations in Fractured Anterior Teeth.-OD0VTOSInt. J. Dental S.C., 16: 47-61. 


\section{RESUMEN}

El objetivo de este estudio clínico fue evaluar la influencia del ángulo cavo superficial (con bisel 0 sin bisel) de restauraciones directas de resina compuesta en dientes anteriores fracturados después de 4 años de desempeño clínico. Las restauraciones se realizaron por un solo operador, siguiendo un protocolo estandarizado. Para el estudio se seleccionaron 24 incisivos centrales superiores con fractura 0 con restauraciones clase IV con una indicación substitución. De acuerdo con la técnica de restauración, las piezas dentales se dividieron en 2 grupos: grupo I $(n=12)$ restauraciones Clase IV con una técnica de preparación con bisel; y grupo II $(n=12)$ restauraciones Clase IV sin ninguna técnica. Las restauraciones se evaluaron a los 7 días y 4 años, por dos examinadores previamente calibrados utilizando criterios USPHS modificados. Después de 4 años, se excluyeron dos sujetos de estudio, lo que representa 22 restauraciones (11 restauraciones con preparación en bisel, y 11 sin preparación de bisel). La prueba de Fisher demostró que no existen diferencias significativas entre los grupos $(p>0,05)$. Este estudio presenta evidencia clínica demostrando que la configuración del ángulo cavo superficial no influye en el desempeño clínico de las restauraciones de resina compuesta directas en dientes anteriores fracturados. Por lo tanto, se recomienda evitar la preparación con bisel del ángulo cavo superficial, con el objetivo de preservar tejido dental sano basado en el enfoque de la Odontología Mínimamente Invasiva.

\section{RELEVANCIA CLÍNICA}

El protocolo clínico para la restauración de dientes anteriores fracturados con resina compuesta se enfoca en practicar una Odontología Mínimamente Invasiva, colocando en práctica todos los conocimientos actuales de la Odontología Adhesiva. Existen estudios laboratoriales confiables que determinan una adecuada adhesión a los substratos dentales. Sin embargo, existe la necesidad de reportar investigaciones clínicas que evalúen el desempeño a largo plazo de las restauraciones adhesivas directas (con bisel y sin bisel) en dientes anteriores fracturados.

\section{PALABRAS CLAVE}

Odontología Mínimamente Invasiva, Resina Compuesta, Restauración Adhesiva Directa, Configuración del Angulo Cavo Superficial, Criterio USPHS.

\section{INTRODUCTION}

The restorative treatment of fractured anterior teeth is a challenge for the dental practitioner. According to the severity of the fracture, different materials and techniques can be used. Currently, one of the treatments of choice is the use of direct adhesive restorations with composite resins. However, according to several published studies, the longevity of this type of restoration is approximately of 3 to 5 years
(Andreasen, 2001; Browning \& Dennison, 1996), 5 to 8 years (Lambrechts, 1990; Smales, 1992) or 6 years (Burke, 2001; Manhart, 2004), which leads to the need for multiple substitutions over the patient's life.

According to Porte et al. (1984) the aesthetic result and the average survival time of restorations in anterior teeth are directly related to the quality of marginal adaptation. With the aim of improving the performance and the probability of survival of 
direct adhesive restorations, numerous studies have been performed (Buonocore \& Davila, 1973; Burke et al., 2001; Sakrana et al, 2004; Nikaido et al., 2007). Even so, doubts remain unclear, such if the cavosurface angle preparation optimizes the clinical performance of these restorations. Some authors recommend that the cavosurface angle preparation is not necessary to improve the aesthetic and functional performance of direct adhesive composite resin restorations (Buonocore \& Davila, 1973; Araujo, 2003; Baratieri, 1995; Gordan, 2000; Milnar, 2005). The bevel preparation prior to restorative treatment has been the most recommended (Denehy, 1980; Fahl \& Swift, 1989; Diestchi, 1995; Diestchi, 2001). However, considering that the fractures of anterior teeth occur frequently in young patients (Andreasen, 1970), it is important to estimate the actual need for the preparation of dental restorations previously fractured. Besides the lack of consensus in the literature, there are few long-term clinical studies evaluating the influence of the cavosurface angle configuration (with bevel and no preparation) in the clinical performance of restorations. Clinical evaluations are of great value when aiming to analyze the performance of restorative materials and techniques since the variables of the oral environment are hardly reproduced in a laboratory. USPHS methodology allows standardization and accuracy in the calibration of the evaluators, which make it a precise method (Gordon, 1974; Burke, 2005).

Based on these considerations, the aim of this study was to evaluate In Vivo the influence of the cavosurface angle configuration (with bevel and no preparation) in the clinical performance of direct adhesive restorations with composite resin in anterior fractured teeth after 4 years of performance.

\section{MATERIALS AND METHODS}

This was a longitudinal, double-blind In Vivo study, with descriptive analysis of the criteria for clinical evaluation. This research evaluated the clinical behavior of these restorations after 4 years of performance; using USPHS modified criteria.

Thus, this study was divided into two stages:

STAGE 1 - RESTORATIVE PROCEDURE AND INITIAL CLINICAL EVALUATION OF RESTORATIONS (ARAUJO JR, 2003).

This phase was subdivided into patient's selection, clinical phase and initial assessment of the restorations.

We selected 17 patients, male and female, who varied from 10 to 25 years of age. To be included in the study, patients had to be with at least one fractured upper central incisor or with a deficient Class IV restoration with an indication of replacement. Therefore, 24 upper central incisors were enrolled in the study. During the procedures of recruitment, periapical radiographs were taken and the pulp vitality test was carried out.

Selected teeth presented pulp vitality and periodontal integrity, and had no color alteration. Furthermore, fractured teeth had a compatible size to receive a direct composite resin restoration.

To participate in research, patients were briefed on the objectives and procedures and signed a term of informed consent in accordance with Resolution No. 169, October 10, 1996, of the National Health Council / Ministry of Health Brasília, DF.

Teeth were randomly divided in two groups:

Group I: consisted mainly of 12 central incisors with a bevel preparation of the cavosurface angle (Figure 1).

Group II: consisted of 12 central incisors with no bevel preparation (Figure 2). 
A single operator performed the restorative treatment, and the technique was described in Araujo Jr. (2003).

After 7 days, clinical evaluation of the restorations was accomplished with the aid of a mouth mirror and an explorer, and under good lighting conditions, with two previously calibrated examiners, which carried out independently the double-blind evaluation.

\section{STAGE 2 - CLINICAL EVALUATION AFTER 4 YEARS OF PERFORMANCE}

After 4 years of performance, 2 patients were excluded due to inability to contact. Therefore, a final sample of 22 teeth with Class IV restorations was evaluated.

Group I: consisting of 11 Class IV direct composite resin restorations performed with a bevel preparation of the cavosurface angle (Figure 1).

Group II: consisting of 11 Class IV direct composite resin restorations performed with no preparation of the cavosurface angle (Figure 2).

The evaluations were conducted based on Cvar \& Ryge modified criteria (2005) of the United States of America Public Health Service (USPHS) system. The evaluations were recorded
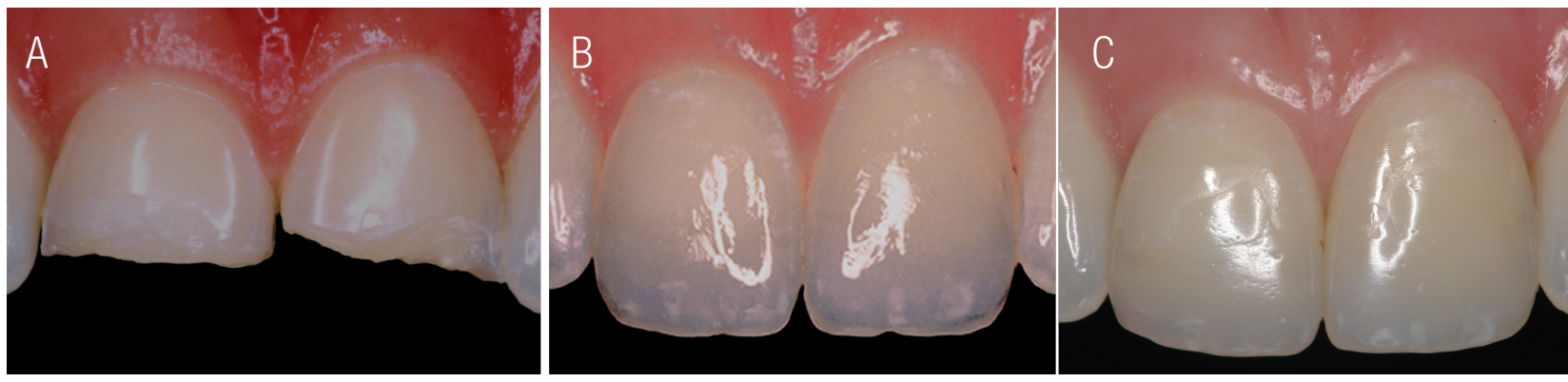

Figure 1. A. Initial frontal view of central upper incisors (Group I: with bevel preparation). B. After Direct Composite Restoration (7 Days evaluation). C. After 4 years of performance.

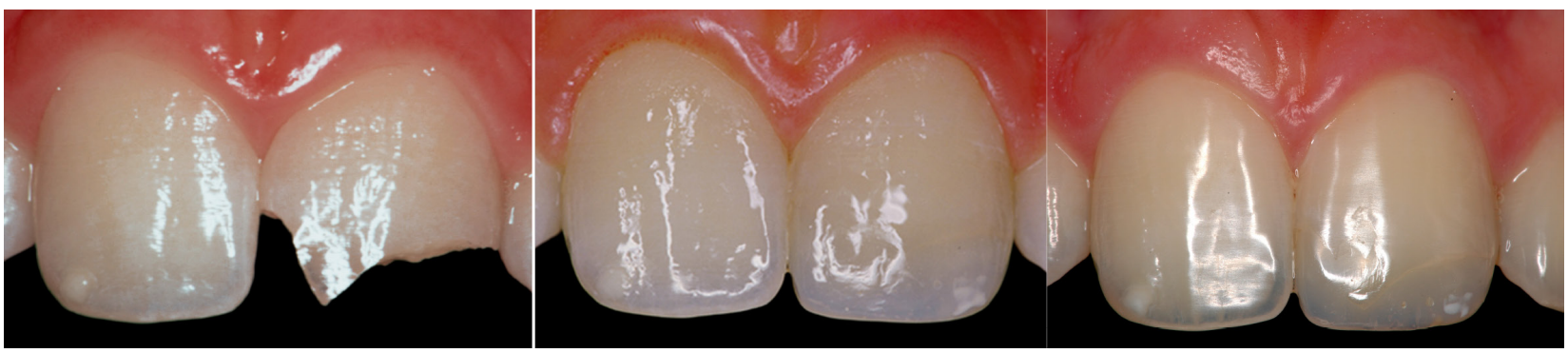

Figure 2. A. Initial frontal view of central upper incisors (Group II: no preparation). B. After Direct Composite Restoration (7 Days evaluation). C. After 4 years of performance.

in a previously prepared form and transferred to an Excel sheet (Microsoft $\circledast$ ) for descriptive statistical analysis. The evaluation criteria and categories are shown in Table 1. As the initial evaluation, this phase was performed with the aid of dental mirror and explorer under good lighting condition and by the same previously calibrated examiners.
Data was analyzed with a significance level of $5 \%$. The descriptive analysis was performed and Fisher's exact test was done in the Statistical Analysis System software (SAS 8.02). We applied the test of proportions for paired data, which examined possible differences between groups, 7 days and 4 years after the performance of restorations. 
Table 1. USPHS Modified Evaluation Criteria (Burke,2005)

\section{Criteria \\ Retention (Ret)}

ALFA:

CHARLIE:

\section{Marginal Integrity (MI)}

ALFA:

BRAVO:

CHARLIE:

DELTA:

\section{Description}

restoration are completely on place

restoration partially or completely lose

no visible evidence of crevice

visible evidence of crevice, therefore dentin isn't exposed

the explorer penetrates into crevice, dentin is exposed

restoration fractured or lost

\title{
Marginal Discoloration (MD)
}

ALFA:

BRAVO:

CHARLIE: no discoloration

discoloration present, therefore with no penetration in a pulpal direction

the discoloration present has penetrated in a pulpal direction

\section{Postoperative sensibility (PS)}

\author{
ALFA: \\ BRAVO: \\ no sensibility \\ with sensibility \\ Incidence of caries (I.Ca) \\ ALFA: \\ BRAVO: \\ no evidence of caries \\ evidence of caries
}

\section{Anatomic form (AF)}

ALFA:

BRAVO:

CHARLIE:

DELTA:

the restoration is continuous with existing anatomic form

the restoration have a little discontinuous with existing anatomic form

the restoration with a moderate discontinuous (sub or sob contour) with existing anatomic form

the restoration is severely discontinued with existing anatomic form

\section{Oclusion (0c)}

ALFA:

BRAVO:

no evidence of stressful oclusal contacts

evidence of stressful oclusal contacts

\section{Periodontal Health (PH)}

ALFA:

BRAVO:

preserve periodontal health

alteration of periodontal health due to restoration 


\section{RESULTS}

Table 2 summarizes the percentage rate for Alfa criteria evaluated in the composite resin restorations with bevel and no preparation, during the first evaluation. The percentage of Alfa evaluation after 4 years is shown in Table 3, representative images are shown in Figure 3, 4 and 5. Table 4 presents the percentages and the odds of Fisher's exact test to examine the relationship between groups and categories for each criteria. The results showed no significant association between groups and categories ( $p>0.05$ ). That is, regardless of whether the tooth was restored with bevel preparation or no preparation, the predominant results were Alfa (Fig. 3, 4, 5). It is important to emphasize that, for retention, postoperative sensibility, incidence of caries, periodontal health and stressful occlusion were not possible to apply a statistical test, because all the values were only in the Alfa category. Therefore, can be stated that no statistical difference was observed between groups (with bevel preparation and no preparation).

Moreover, only 3 restorations shows Bravo score, 1 in the group with bevel preparation and 2 for the group with no preparation. One restoration of group I showed Bravo score for marginal integrity, marginal discoloration and axial contour. Whereas, group II showed Bravo score in one restoration with marginal integrity and two with marginal discoloration and axial contour.

Table 2. Alfa percentage for experimental groups after 7 days evaluation

\begin{tabular}{lllllllll}
\hline Criteria & Ret & MI & MD & PS & I. Ca & AF & Oc & PH \\
\hline With bevel & $100 \%$ & $100 \%$ & $100 \%$ & $100 \%$ & $100 \%$ & $100 \%$ & $100 \%$ & $100 \%$ \\
No prep. & $100 \%$ & $100 \%$ & $100 \%$ & $100 \%$ & $100 \%$ & $100 \%$ & $100 \%$ & $100 \%$ \\
Total & $100 \%$ & $100 \%$ & $100 \%$ & $100 \%$ & $100 \%$ & $100 \%$ & $100 \%$ & $100 \%$ \\
N= & 24 & 24 & 24 & 24 & 24 & 24 & 24 & 24 \\
\hline
\end{tabular}

Table 3. Alfa percentage for experimental groups after 4 years of performance

\begin{tabular}{lllllllll}
\hline Criteria & Ret & MI & MD & PS & I.Ca & AF & Oc & PH \\
\hline With bevel & $100 \%$ & $90,9 \%$ & $90,0 \%$ & $100 \%$ & $100 \%$ & $90,9 \%$ & $100 \%$ & $100 \%$ \\
No prep. & $100 \%$ & $90,9 \%$ & $86,4 \%$ & $100 \%$ & $100 \%$ & $86,4 \%$ & $100 \%$ & $100 \%$ \\
Total & $100 \%$ & $90,9 \%$ & $86,4 \%$ & $100 \%$ & $100 \%$ & $86,4 \%$ & $100 \%$ & $100 \%$ \\
N= & 24 & 24 & 24 & 24 & 24 & 24 & 24 & 24 \\
\hline
\end{tabular}


Table 4. Association between groups vs. categories for each criteria after 4 years of performance

\begin{tabular}{|c|c|c|c|c|}
\hline \multirow{2}{*}{ Criteria } & \multirow{2}{*}{ Rating } & \multicolumn{2}{|l|}{ Groups I \& II } & \multirow{2}{*}{ p-value } \\
\hline & & With bevel & No prep. & \\
\hline \multirow[t]{2}{*}{ Retention } & \multirow[t]{2}{*}{ Alfa Charlie } & $11(100,0 \%$ & $11(100,0 \%)$ & \multirow[t]{2}{*}{---} \\
\hline & & $0(0,0 \%)$ & $0(0,0 \%)$ & \\
\hline \multirow[t]{2}{*}{ Marginal Integrity } & \multirow[t]{2}{*}{ Alfa Bravo } & $10(90,9 \%)$ & $10(90,9 \%)$ & \multirow[t]{2}{*}{0,7619} \\
\hline & & $1(9,1 \%)$ & $1(9,1 \%)$ & \\
\hline \multirow[t]{2}{*}{ Marginal discolour } & \multirow[t]{2}{*}{ Alfa Bravo } & $10(90,9 \%)$ & $9(81,8 \%)$ & \multirow[t]{2}{*}{0,8929} \\
\hline & & $1(9,1 \%)$ & $2(18,2 \%)$ & \\
\hline \multirow[t]{2}{*}{ Postop. Sensibility } & \multirow[t]{2}{*}{ Alfa Bravo } & $11(100,0 \%)$ & $11(100,0 \%)$ & \multirow[t]{2}{*}{---} \\
\hline & & $0(0,0 \%)$ & $0(0,0 \%)$ & \\
\hline \multirow[t]{2}{*}{ Incidence of caries } & \multirow[t]{2}{*}{ Alfa Bravo } & $11(100,0 \%)$ & $11(100,0 \%)$ & \multirow[t]{2}{*}{---} \\
\hline & & $0(0,0 \%)$ & $0(0,0 \%)$ & \\
\hline \multirow[t]{2}{*}{ Anatomical form } & \multirow[t]{2}{*}{ Alfa Bravo } & $10(90,9 \%)$ & $9(81,8 \%)$ & \multirow[t]{2}{*}{0,8929} \\
\hline & & $1(9,1 \%)$ & $2(18,2 \%)$ & \\
\hline \multirow[t]{2}{*}{ Stressful oclussion } & \multirow[t]{2}{*}{ Alfa Bravo } & $11(100,0 \%)$ & $11(100,0 \%)$ & \multirow[t]{2}{*}{---} \\
\hline & & $0(0,0 \%)$ & $0(0,0 \%)$ & \\
\hline \multirow[t]{2}{*}{ Periodontal Health } & \multirow[t]{2}{*}{ Alfa Bravo } & $11(100,0 \%)$ & $11(100,0 \%)$ & \multirow[t]{2}{*}{---} \\
\hline & & $0(0,0 \%)$ & $0(0,0 \%)$ & \\
\hline
\end{tabular}

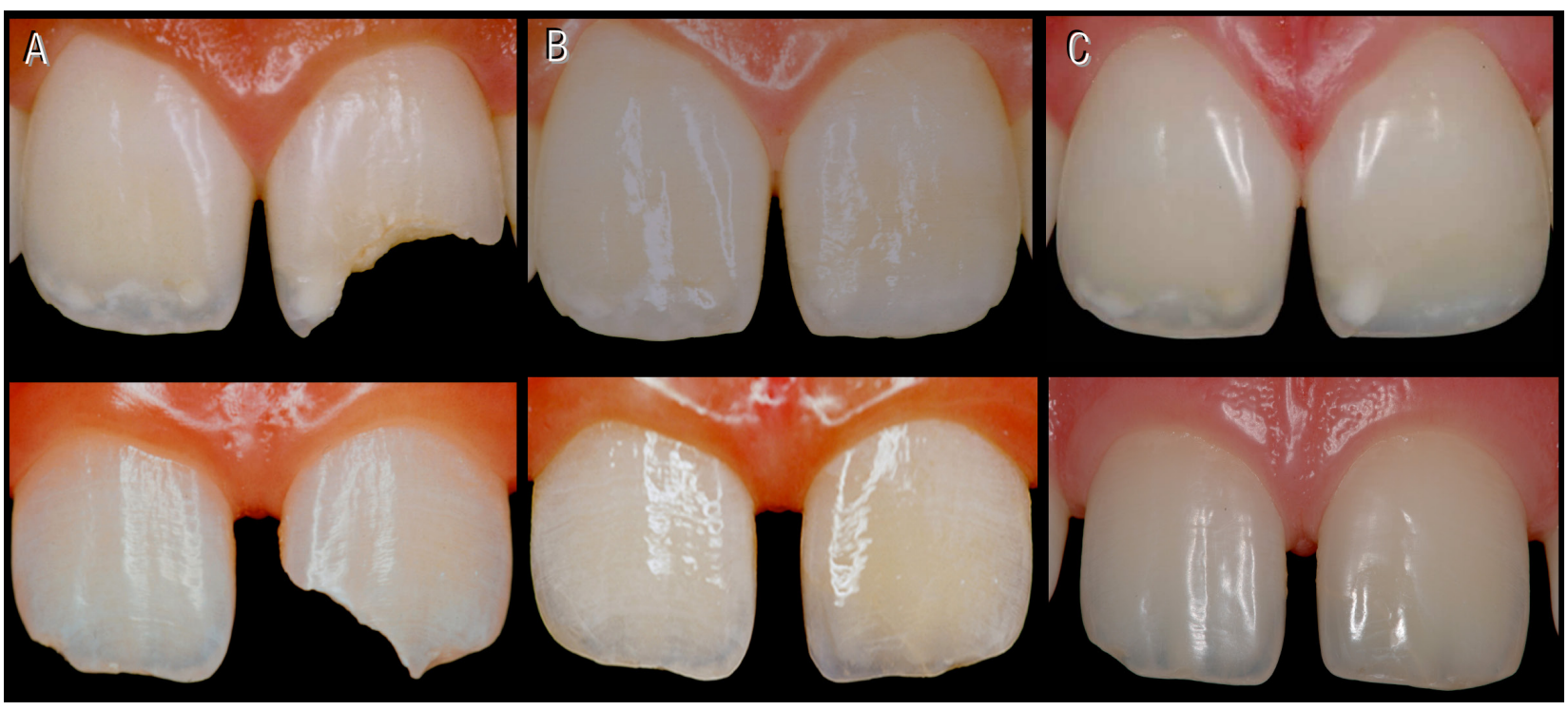

Figure 3. A. Initial frontal view of central upper incisors (Group II: no preparation). B. After Direct Composite Restoration (7 Days evaluation). C. After 4 years of performance. Both restorations were categorized as Alfa Score after 4 years of clinical performance. 

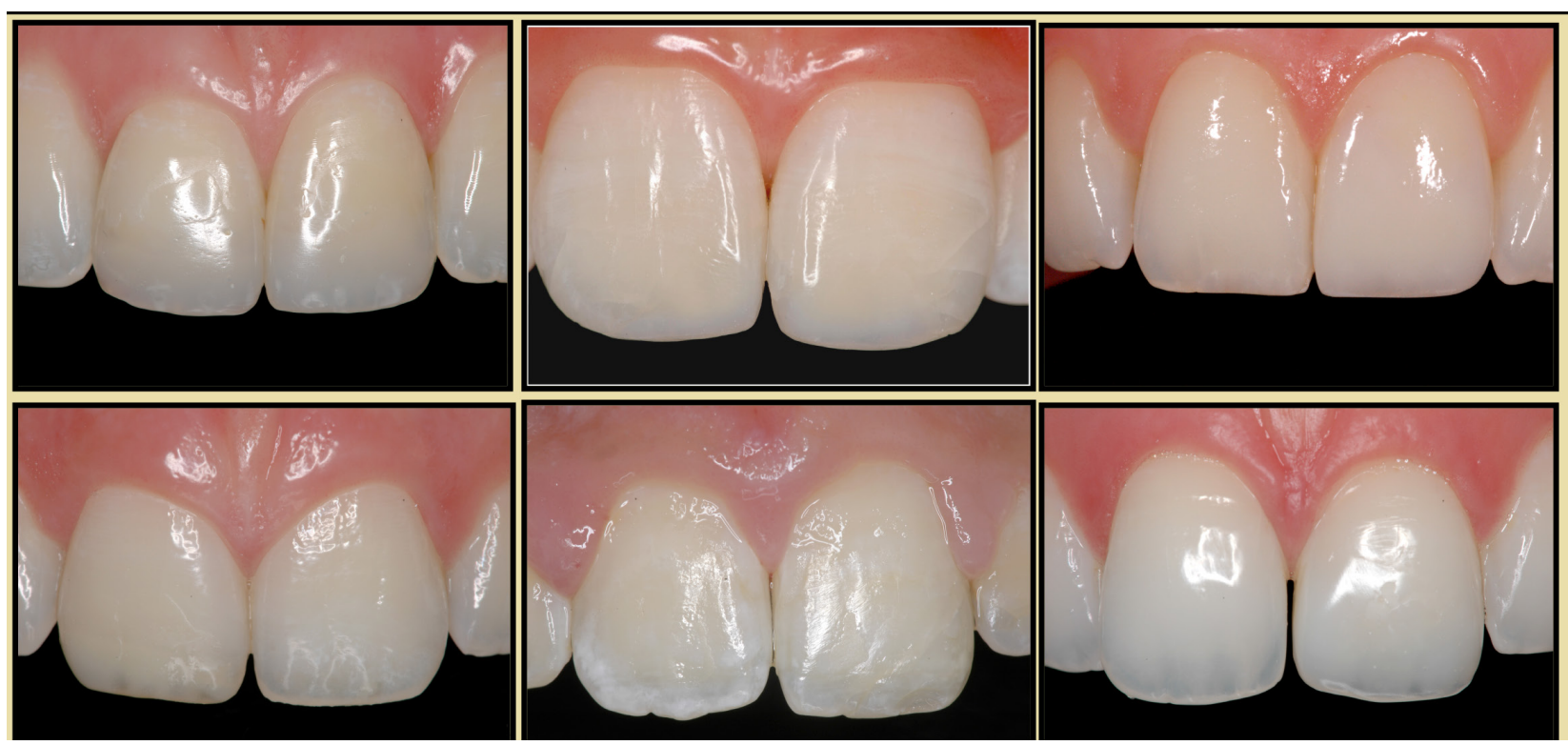

Figure 4. Representative images of Class IV Restorations (Group I - with) bevel preparation categorized as Alfa Score after 4 years of clinical performance.

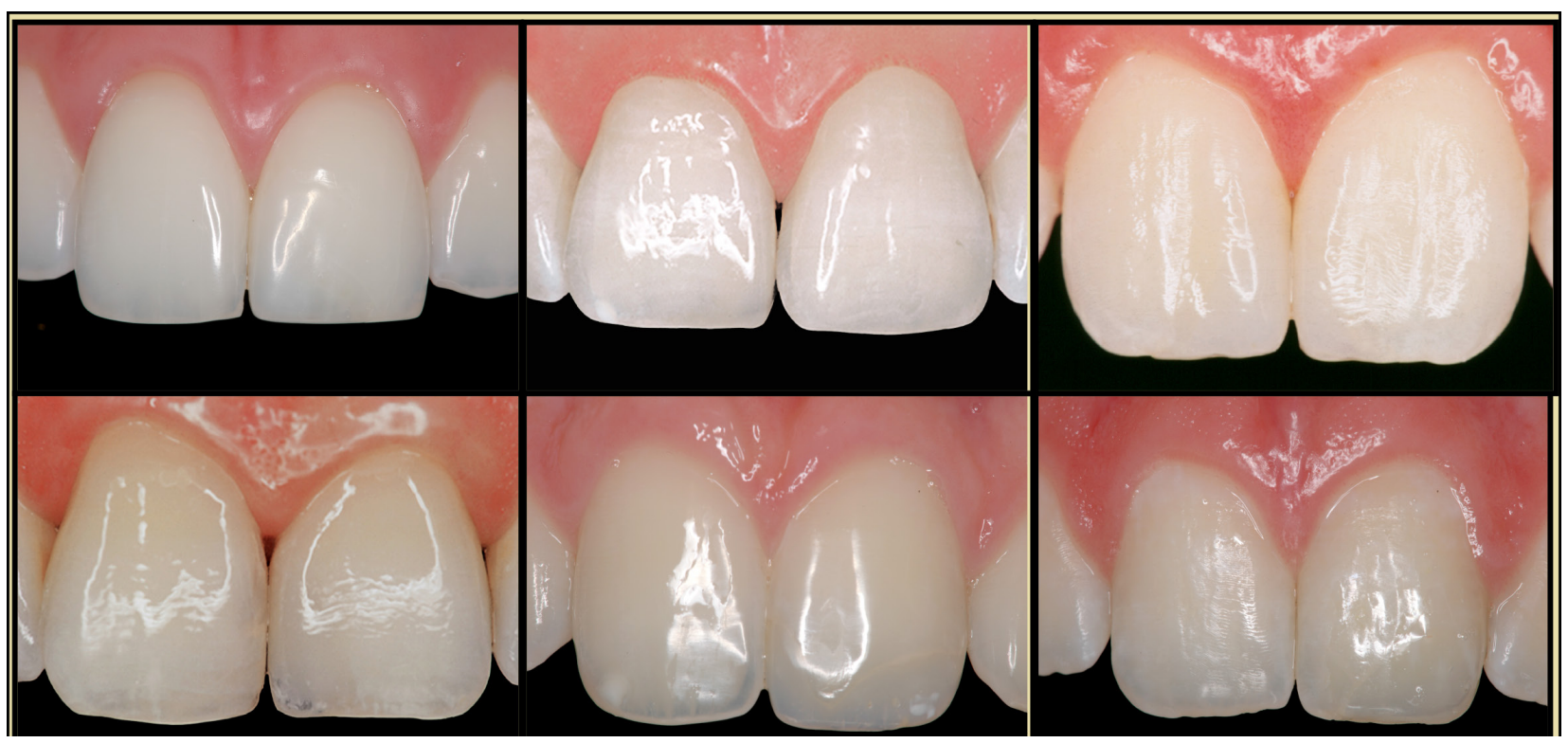

Figure 5. Representative images of Class IV Restorations (Group II - no preparation) categorized as Alfa Score after 4 years of clinical performance. No preparation of the cavosurface angle aims to preserve sound dental tissue based on a Minimally Invasive Dentistry approach. 
DISCUSSION

Coronal fractures can occur at any age, but generally affects children and teenagers (Andreasen \& Andreasen, 1994). Due to its high incidence and the main involvement of anterior teeth, deserve special attention. Direct adhesive restoration is the treatment more commonly used for conservative restoration of such defect (Fahl Jr \& Swift Jr, 1989). The combination of aesthetic expectation of the patient and desire for the development of a conservative treatment by the dentist resulted in the implementation of different clinical protocols (Terry, 2000; Ramirez et al., 2011).

The Restorative Dentistry currently recommends minimally invasive procedures to prevent the unnecessary removal of healthy sound tooth structure during the restorative procedure (Araujo Jr. et al, 2003a; Araujo Jr. et al, 2003b; Ardu \& Krejci, 2006; Dos Santos \& Maia, 2006; Franco et al., 2007; Ramirez et al., 2011).

Several studies have suggested the preparation of a bevel in order to provide better retention of the restoration, as well as to mask the fracture line (Eriksen \& Buonocore, 1976; Bagheri \& Denehy, 1985; Hoelscher et al., 2000; Felippe et al., 2005; Vargas, 2007). Moreover, allowing the preservation of dental structure, some authors advocate for restoring a clinical protocol with no preparation (Buonocore \& Davila, 1973; Araujo Jr., 2003; Peters \& McLean, 2001; Gondo, 2003; Gondo et al., 2005; Milnar, 2005; Ramirez et al., 2011).

The influence of the cavosurface angle configuration (with bevel and no preparation) after 4 years of clinical performance of direct adhesive restorations with composite resin in anterior fractured teeth, was evaluated through a USPHS modified criteria (Chadwick et al., 1991; Gordon, 1994; Hickel et al., 2007). This methodology was employed due to their reliability, standardization, low operational costs and easy implementation. The protocol of clinical evaluation is a widely accepted methodology, which defines the parameters of clinical importance in the performance of restorations and provides an excellent system for calibration of the evaluators. Several studies have used this methodology with satisfactory results (Crumpler et al., 1988; Jokstad et al., 1994; De Souza, 2005).

Van Dijken (1986) noted that most clinical evaluations are conducted in 3 years or less. The period of 2 years is insufficient to evaluate the properties of the tested materials, but may indicate a trend of their future clinical performance. Therefore, this study provided valuable information to prepare a prognosis about the two restorative techniques analyzed.

Developments in knowledge of enamel and dentin substrates, plus the improvement of adhesive agents, improved the clinical performance of direct adhesive restorations with composite resin in relation to marginal microleakage (Nakabayashi \& Pashley, 2000). The highest wear resistance of composite resins has been provided by the evolution of the composition, size and quantity of charge particles (Martins et al., 2002). Nevertheless, resin composite materials are still very sensitive, enhancing the need to be continually clinically tested, since it is virtually impossible to reproduce in the laboratory the complexity of the oral environment.

A primary and important criteria to be evaluated in clinical studies is the permanence of the material in the place inserted, representing the retentive capacity of the restorative technique used (Hand et al., 1986).

The development of the etching technique by Buonocore (1955) changed the concept of cavity preparation for fractured anterior teeth, more than any other principle (Bagheri \& Denehy, 1983). These results were complemented by Bowen et al. (1982) who study the responsible mechanisms for adhesion of restorative materials to dental tissues and the improvement of techniques and adhesive materials. 
With the introduction of composite resins, from the 1970s, and their significant development in recent years, the ability of adhesion to enamel and dentin was improved employing the total etch technique, initially proposed by Fusayama et al. (1979).

In this study, the restorations were evaluated under a strict protocol. Enamel and dentin were used as substrate for adhesion. So as expected, after 4 years, all restorations (100\%) with and without bevel preparation remained intact. Peutzfeldt and Asmussen (2002) concluded that when the restorative materials are of excellent quality and handled according to manufacturers' instructions, you can considerably reduce the factors that can negatively influence the retention. The percentage of retention of this study is difficult to compared with other data in current dental literature because the initial sample of patients is not preserved over time. However, recent studies suggest that the direct composite resins have an average lifetime of about 5 to 6 years (Burke et al., 2001; Manhart et al., 2004).

The marginal adaptation is directly linked to the marginal integrity for any restorative material and is associated with several factors such as contraction of polymerization. Moreover, dimensional changes are associated with the coefficient linear of thermal expansion (Peutzfeldt \& Asmussen, 2002). The removal of fragile or already fractured enamel at the margins can contribute with the marginal integrity, which is applicable to all materials (Peutzfeldt \& Asmussen, 2002).

In the restorations of group 1, the enamel margins that were very fragile or broken were removed and a bevel preparation was performed in an appropriate manner. This procedure aims to allow a greater thickness of the resin layer and a proper fusion between the restorative material and tooth, to mask the line of union improving the aesthetic results, and consequently, allowing minimizing microleakage and marginal discoloration (Crim, 1978; Hardison, 1987; Owens et al., 1988; Hirata, 2001; Eid, 2002).

According to Boston (1882) the bevel should not be performed when the objective is to improve the marginal sealing. This may explain the fact that in our study, no significant difference was shown between groups regarding marginal integrity. Another significant aspect is that the restorations evaluated in this research were finished and polished 7 days after being performed, allowing the water absorption of polymers, which should have also contributed positively to the marginal integrity.

In our study, from the 22 restorations evaluated, $2(9.1 \%)$ had cracks in the margin after 4 years, 1 in each group. This result shows no difference between the two groups studied, but demonstrates that none of the procedures on the cavosurface angle configuration was able to eliminate completely the alterations on the restorative margin.

The good performance of the restorations for marginal integrity after 4 years of assessment can be attributed to the effectiveness of the technique with which the restorations were performed, the employment of the total etching technique, the application of adhesive system (Scothbond MultiPurpose Plus, 3M ESPE), adding the composite resin with a modified layering technique, and the finishing and polishing procedures (Ramirez et al., 2011).

The placement of composite resin in the cavity is an aspect that can determine the staining of the margins of the restoration with time. The insertion of the composite beyond the enamel conditioning can result in failure of the union between the composite resin and tooth. In this case, besides the degradation of the margin, may occur the deposition of organic materials and pigments from food and other habits that promote a discoloration of the margin of the restoration (Bowen et al., 1982). 
The composite resin of microparticles and micro-hybrid used in the reconstruction of buccal and palatal enamel, respectively, has different proportions between load and organic matrix. If the proportion of organic matrix in the composite resin is higher, the absorption of water or the hygroscopic expansion becomes greater and, consequently, more effective the marginal sealing (Hirata, 2001). However, the results of this research have shown, after 4 years of performance, marginal discoloration in only 3 restorations, all at the vestibular side, where was restored with a microparticles composite resin. It is likely that due to this fact, the composite resins have not achieved an extraordinary degree of hygroscopic expansion, but was enough to allowed an effective adaptation of resin at the margins or a crack so small that was not detected by the explorer of the examiner.

In our study, one restoration with bevel preparation (9.1\%) and two without preparation (18.2\%) registered a Bravo category for marginal discoloration. These findings differ from those found by Villela et al. (1987) which showed that no preparation showed better results when compared with the bevel preparation technique. Based on these results, we can suggest that the bevel preparation has not decreased the occurrence of marginal discoloration after 4 years of performance. However, it was observed that there were a greater number of restorations with marginal discoloration than with marginal integrity, which is an indication that marginal discoloration does not necessarily translate into failure of marginal integrity, since the marginal discoloration may occur by the presence of reparative secondary dentin formed over time.

The dimensional stability of composite resin is important in order to remain unchanged the marginal integrity and marginal discoloration through time. Repeated temperature alterations can induce tension on the adhered margins, if the coefficients of thermal expansion of the tooth and the restorative material are not similar, due to the tension generated during polymerization. Both, the temperature and the $\mathrm{pH}$ of the oral environment are subjected to fluctuations. The complexity of the oral environment, coupled with the fact that the coefficient of thermal expansion of composite resins is greater than the tooth structure, promotes that they behave in different manner (Feilzer et al., 1989). Crumpler et al. (1988) showed that the composite resins with lower content of loads and higher coefficient of thermal expansion exhibited higher incidences of marginal discoloration. These findings may be associated to our results in which the palatal restorations showed no changes on marginal discoloration. A possible explanation may be related to the use of micro-hybrid composite resins, which have low coefficient of thermal expansion and a high load content, which, consequently, minimize the formation of cracks and marginal pigmentation.

Brännström (1977) based on the hydrodynamic theory, explained the tooth sensitivity exerted by the fluid movement in dentinal tubules according to the thermal expansion. When performing photopolymerization, the contraction of the composite resin causes tension at the tooth/restoration interface. Depending upon the magnitude of the forces generated in these areas, may cause the breaking of the adhesive connections and the formation of cracks, which can cause irreversible problems of clinical hypersensitivity. The crack caused by the contraction may be filled by tissular fluid and bacteria from proliferating sources of nutrients of oral cavity. The sequels may be secondary caries, pulp inflammation and hypersensitivity.

In this study, the total absence of sensitivity in the immediate postoperative period and after 4 years for both groups indicates that the hybridization of dentin provides adequate protection and health maintenance of the dentin/ pulp complex. In all restorations evaluated in this work, the protection of the dentin/pulp complex 
was performed by hybridization of dentin, although not always have a good amount of dentin between the pulp and restoration. This makes us suggest that the sealing done by hybridization provided conditions for the absence of postoperative sensitivity, demonstrating that the effectiveness of the adhesive protocol used is more important that the configuration of the cavosurface angle (Nakabayashi \& Pashley, 2000).

The interface of a composite resin restoration allows microbial colonization, and if the patients do not maintain an adequate oral hygiene this fact becomes even more negative. This statement reinforces the need that during the initial evaluation of patients an implementation of oral hygiene has to be carried out aiming to reduce the risk of caries. In this study, the evaluators did not discovered any case of secondary caries, which can be attributed to the fact that patients were properly instructed and have maintained an adequate oral hygiene through the research.

During the evaluation period, was difficult to evaluate changes in axial contour. These possible excesses were perceived with the aid of the explorer and recorded as a soft sob contour, therefore classified as Bravo. Subtle differences at the margins between the surface of the restorative material and the tooth surface generated doubts whether or not there was discontinuity with the existing dental form. In our study, was found in group I (with bevel) one restoration with overcontour (category Bravo) and in group II (without preparation) two restorations with the same characteristic (Bravo category). Therefore, no significant difference was observed between groups. Composite resin restorations analyzed in this study showed anatomical form variations, receiving a total percentage for Bravo Score of $13.6 \%$. This finding may be associated to loss of particles displaced from the surface of the organic matrix, the wear of the restoration and change in their anatomical macro and micro geometrics over time.
According to Shortall et al. (1995) the insufficient conversion of monomer to polymer can result in an inadequate resistance to wear. In an unpolymerized layer of composite resin is expected to affect most of these properties.

Based on our statistical results, we can state that the value of $100 \%$ for both groups in occlusion stress test suggest that all reference points, regarding our strict restoration protocol with the help of a silicone guidance and implementation of closure diagnoses and adjustment of occlusion points, led to the success of the restorations during the period of 4 years.

Periodontal health was not affected in this study for any of the groups studied. This is due to several factors: the fracture selected for replacement does not compromise the periodontal tissues, the restorations were executed properly and had an appropriate degree of polishing and marginal adaptation which minimized the accumulation of plaque and facilitated the cleaning.

Composite resin used with a biomimetic approach should be considered the main alternative for esthetic restorations (Ramirez et al., 2011). According to the USPHS clinical evaluation method adopted, all the criteria demonstrate no statistical difference between the two restorative techniques (with bevel and no preparation) at both moments of assessment. Therefore, our study evidenced that both techniques display a similar clinical performance. Thus, we can suggest that it is possible to perform Class IV direct restorations with composite resin without any prior mechanical preparation, allowing the preservation of sound dental tissue and integrating a Minimally Invasive Dentistry Approach.

\section{CONCLUSION}

Based on our results, it was demonstrated that the mechanical bevel preparation of the 
cavosurface angle does not provide a better clinical performance of Class IV adhesive restorations with direct resin composite, demonstrating the possibility to restore class IV fractured anterior teeth without the unnecessary removal of sound dental tissue.

\section{REFERENCES}

Andreasen J0 (1970) Etiology and pathogenesis of traumatic dental injuries. A clinical study of 1,298 cases. Scandinavian Journal of Dental. Research 78(4) 329-342.

Andreasen J0 \& Andreasen FM (1994) Textbook and color atlas of traumatic injuries to the teeth Mosby, Missouri.

Andreasen J0 (2001) Buonocore memorial lecture. Adhesive dentistry applied to the treatment of traumatic dental injuries. Operative Dentistry 26(4) 328-335.

Araujo Jr EM (2003) Influence of the cavosuperficial angle configuration in the esthetic result of direct restorations on fractured anterior teeth. 2003. $189 \mathrm{f}$. Thesis (Doctor degree in Dentistry) - Pos-graduate student, Federal University of Santa Catarina, Florianópolis, 2003.

Ardu S \& Krejci I (2006) Biomimetic direct composite stratification technique for the restoration of anterior teeth. Quintessence International 37 (3) 167-174.

Bagheri J \& Denehy G (1985) Effect of restoration thickness at the cavosurface bevel on the class IV acid-etched retained composite resin restoration Journal of Prosthetic Dentistry 54 (2) 175-177.

Bagheri J \& Denehy GE (1983) Effect of enamel bevel and restoration lengths on Class IV acidetch retained composite resin restoration. Journal American Dental. Association 107(6) 951-952.

Baratieri LN (1995) Esthetic: Direct restorative dentistry in fractured anterior teeth Quintessence, São Paulo.

Bowen RL, Rapson JE \& Dickson G (1982) Hardening shrinkage and hygroscopic expansion of composite resins. Journal of Dental Research 61(5) 654-658.

Brännström M. (1986) The hydrodynamic theory of dentinal pain: sensation in preparations, caries and the dentinal crack syndrome. J. Endod. 12(10) 453-457.

Browning WD \& Dennison JB (1996) A survey of failure modes in composite resin restorations Operative Dentistry 21(4) 160-166.

Boston DW (1982) Rationale and technique for composite resin restorations. Part III. Principles of cavity design and restoration. Compendium of Continuing. Education in Dentistry 3(4) 253-258.

Buonocore MG (1955) A Simple method of increasing the adhesion of acrylic filling materials to enamel surfaces. Journal of Dental Research 34 (6) 849-853.

Buonocore MG \& Davila J (1973) Restoration of fractured anterior teeth with ultraviolet light-polymerized bonding materials: A new technique. Journal of the American Dental Association 86(6) 1349-1354.

Burke FJ, Crisp RJ, Bell TJ, Healy A, Mark B, McBirnie R \& Osborne-Smith KL (2001a) One-year retrospective clinical evaluation of hybrid composite restorations placed in United Kingdom general practices Quintessence International 32(4) 293-298.

Burke FJ, Wilson NH, Cheung SW \& Mjör IA (2001b) Influence of patient factors on age of restorations at failure and reasons for their placement and replacement Journal of Dentistry 29(5) 317-324.

Burke FJ (2005) Evaluating restorative materials and procedures in dental practice Advances in Dental Research 18(3) 46-49.

Chadwick RG, McCabe JF, Walls AW, Mitchell HL \& Storer R (1991) Comparison of a novel photogrammetric techique and modified USPHS criteria to monitor the wear of restorations. Journal of Dentistry 19(1) 39-45.

Crim GA (1978) Management of the fractured incisor. Journal of the America Dental Association 96(1) 99-100. 
Crumpler DC, Heymann HO, Shugars DA, Bayne SC \& Leinfelder KF (1988) Five-year clinical investigation of one conventional composite and three microfilled resins in anterior teeth Dental Materials 4(4) 217-222.

Cvar JF \& Ryge G (2005) Reprint of criteria for the clinical evaluation of dental restorative materials. 1971 Clinical Oral Investigation 9(4) 215-232.

De Araujo Jr EM, Baratieri LN, Monteiro Júnior S, Vieira LC \& de Andrada MA. (2003a) Direct adhesive restoration of anterior teeth: Part 1. Fundamentals of excellence Practical Procedures \& Aesthetic Dentistry 15 (3) 233-240.

De Araujo Jr EM, Baratieri LN, Monteiro S Jr, Vieira LC, \& de Andrada MA (2003b).Direct adhesive restoration of anterior teeth: Part 2. Clinical protocol. Practical Procedures \& Aesthetic Dentistry 15(5) 351-357.

Denehy GE, Doering JV \& Torney DL (1980) Occlusion for successful class IV acid-etch restorations Journal of Prosthetic Dentistry 44(3) 274-278.

Dietschi D (1995) Free-hand composite resin restorations: a key to anterior aesthetics. Practical Periodontic and Aesthetic Dentistry 7(7) 15-25.

Dietschi D (2001) Layering concepts in anterior composite restorations Journal of Adhesive Dentistry 3(1) 71-80.

De Souza FB, Guimarães, RP \& Silva CH (2005) A clinical evaluation of packable and microhybrid resin composite restorations One-year report Quintessence International 36 (1) 41-48.

Dos Santos MP \& Maia LC (2005) The reference guide: a step by step technique for restoration of fractured anterior permanent teeth Journal Canadian Dental Association 71(9) 643-646.

Eid H. (2002) Retention of composite resin restorations in class IV preparations Journal of Clinical. Pediatric Dentistry 26(3) 251-256.

Eriksen HM \& Buonocore MG (1976) Marginal leakage with different composite restorative materials in vitro. Effects of cavity design. Journal of Oral Rehabilitation 3(4) 315-322.
Fahl N Jr \& Swift EJ Jr (1989) The invisible class IV restoration Journal of Esthetic Dentistry 1(4) 111-113.

Felippe LA, Monteiro S Jr, De Andrada CA \& Ritter AV (2005) Clinical strategies for success in proximoincisal composite restorations. Part II: Composite application technique. Journal Esthetic and Restorative. Dentistry 17(1) 11-21. Franco EB, Francischone CE, Medina-Valdivia JR \& Baseggio W (2007) Reproducing the natural aspects of dental tissues with resin composites in proximo incisal restorations Quintessence International 38 (6) 505-510.

Fusayama T, Nakamura M, Kurosaki N \& Iwaku M. (1979) Non-pressure adhesion of a new adhesive restorative resin. Journal of Dental Research 58(4)1364-1370.

Gordan VV (2000) In vitro evaluation of margins of replaced resin-based composite restorations Journal of Esthetic Dentistry 12(4) 209-215.

Gordon DF (1974) Quality standards: Their establishment for Dentistry Journal California Dental Association 2(4) 43-45.

Gondo, R. Influence of cavo-surface configuration in the esthetic result of composite resin restoration in anterior fractured teeth - An in vitro study. 2003. 155 f. Dissertation (Master Degree in Dentistry) - Pos-Graduation Program in Dentistry, Federal University of Santa Catarina, Florianópolis, 2003.

Gondo A, Marson FC, I Álvares (2005) Direct composite resin restorations in anterior teeth: some grounds for obtaining good aesthetic results. Clinic-Int. Brazilian Journal Dent 1 (2) 37-145.

Hand JS, Hunt RJ \& Reinhardt JW (1986) The prevalence and treatment implications of the cervical abrasion in the elderly. Gerodontics (2)167-170.

Hardison JD (1987) Preparation and restoration of anterior teeth with composite resin: a survey of dental schools. Operative Dentistry 12(3) 95-99. Hickel R, Roulet JF, Bayne S, Heintze SD, Mjör IA, Peters M, Rousson V, Randall R, Schmalz G, 
Tyas M, \& Vanherle G (2007) Recommendations for conducting controlled clinical studies of dental restorative materials. Clinical Oral Investigations 11(1) 5-33.

Hirata R, Ampessan RL, Liu J (2001) Reconstruction of anterior teeth with composite resin a sequence of choice and use of resins. JBC 5 (25) 15-25. Hoelscher DC, Gregory WA, Linger JB \& Pink FE. (2000) Effect of light source position and bevel placement on facial margin adaptation of resin-based composite restorations. American Journal of Dentistry 13(4) 171-175.

Jokstad A, Mjör IA, Nilner K \& Kaping S (1994) Clinical performance of three anterior restorative materials over 10 year Quintessence International 25(2) 101-108.

Lambrechts P, Willems G, Vanherle G \& Braem M (1990) Aesthetic limits of light-cured composite resins in anterior teeth International Dental Journal 40(3) 149-158.

Manhart J, Chen H, Hamm G \& Hickel R (2004) Buonocore Memorial Lecture. Review of the clinical survival of direct and indirect restorations in posterior teeth of the permanent dentition Operative Dentistry 29(5) 481-508.

Martins, F. et al (2002) Resin microhardness in function of color and halogen light. Pesq. Odontol. Bras 16 (3) 46-250.

Milnar FJ (2005) Mastering minimal intervention and discretionary aesthetic procedures when placing direct composites. Practical Procedures \& Aesthetic Dentistry 17(6) 428-432.

Nakabayashi N \& Pashley DH (2000.) Hybridization of Dental Hard Tissues Quintessence São Paulo. Nikaido T, Takada T, Kitasako Y, Ogata M, Shimada Y, Yoshikawa T, Nakajima M, Otsuki M, Tagami J \& Burrow MF. (2007) Retrospective study of the 10-year clinical performance of direct resin composite restorations placed with the acidetch technique. Quintessence International 38(5) 240-246.

Owens, BM, Halter TK \& Brown DM (1998) Microleakage of tooth-colored restorations with a beveled gingival margin Quintessence International 29(6) 356-361.

Peutzfeldt A \& Asmussen E (2002) Adhesive System: effect on bond strength of incorrect use Journal of Adhesive Dentistry 4(3) 233-242.

Peters MC \& McLean ME (2001) Minimally invasive operative care. I. Minimal intervention and concepts for minimally invasive cavity preparations. Journal of Adhesive Dentistry.3(1) 7-16.

Porte A, Lutz F, Lund MR, Swartz ML \& Cochran MA. (1984) Cavity designs for composite resins Operative Dentistry (9) 50-56.

Sakrana AA, Tanoue N, Kawasaki K, Matsumura $H$ (2004) One-year clinical evaluation of two composite materials used for anterior class $\mathrm{V}$ restorations Journal of Oral Rehabilitation 31(10) 985-990.

Smales RJ, Webster DA \& Leppard PI (1992) Predictions of restoration deterioration Journal of Dentistry 20(4) 215-220.

Shortall AC, Wilson HJ \& Harrington E (1995) Depth of cure of radiation activated composite restoratives - influence of shade and opacity. Journal of Oral Rehabilitation 22(5) 337-342.

Terry DA (2000) Direct composite resin restoration of adolescent class IV tooth fracture: a case report. Practical Periodontics and Aesthetic Dentistry 12(1) 23-29.

Van Dijken JW (1986) A clinical evaluation of anterior conventional, microfiller, and hybrid composite resin fillings $A$ 6-year follow-up study Acta Odontologica. Scandinavica 44(6) 357-367.

Vargas M (2007) Conservative aesthetic enhancement of the anterior dentition using a predictable direct resin protocol. Practical Procedures and Aesthetic Dentistry 18(8) 501-507.

Villela LC, Araújo MAJ, Rossetini SMO (1987) Cavities preparation for fractured anterior teeth. RGO 35 (6) 447-451. 